\title{
From Blue Star Line to Star Reefers
}

Star Reefers is one of the few remaining independent reefer operators and has a fleet of modern vessels chartered to the major fruit companies. Today's operation is owned by Siem Industries and is a result of Siem's fusion of its previously acquired Swan Reefers and its purchase of the remaining vestige of the classic Blue Star Line. The latter, with its famous funnel logo, can trace its history back over a hundred years and its fortunes were inextricably linked to that of its owners and founders, the Vestey family.

In the late nineteenth century Samuel Vestey, a provisioner with a butchery, sent his sons, William and Edmund to the UsA where a meat cannery in Chicago was established. The idea was to produce low cost corned beef to the business back in Liverpool. This venture was followed by the export from Argentina of frozen partridges and this gave the brothers exposure to the new technology of refrigeration leading them to open a cold store in England. The business was apparently successful and was publicly listed in $1897^{1}$. In 1903 the business had expanded with several cold stores around England as well as one in Riga ${ }^{2}$. The basic business idea was a follow-on from the meat cannery in Chicago: to provide cheap meat products to England and to the Merseyside in particular. The Vesteys identified that the burgeoning industrial population of the region was a potentially massive meat consumer, as long as it was inexpensive, and were able to tap into that demand.

It's fair to say that the Vesteys were pioneers in the application of refrigeration technology. The network of cold stores was expanding and, with hindsight, we can consider this as a necessary infrastructure that was a prerequisite for the development of refrigerated shipping. The Vesteys initiated a new venture from China in 1906 and the major business was eggs for the bakeries in the UK. Even though the Vesteys are associated with the meat trades it was the egg trade that led them to purchase two steamers that were converted to refrigerated vessels in 1909 .

The Vestey brothers formed Blue Star Line in 1911. The fleet grew and Argentina became a major centre for their operations, a cold store was opened at Zárate and the Allied armies in France were supplied with meat during the

1 Initial prospectus of the Union Cold Storage and Ice Company of Liverpool Limited from the Liverpool Daily Post, 23 Nov 1897, p.4.

2 The Standard, 17 Nov 1903, p 11. 
First World War. In Britain the Vesteys invested in retail butcheries that numbered over 2000 by the twenties. And by the 1925 Blue Star Line claimed to have the largest refrigerated fleet in the world ${ }^{3}$.

The vessels that Blue Star Line operated at this time had little in common with the reefers that we come across later in the century. These were multipurpose vessels with a frozen hold for meat, a regular hold for general cargo and they also carried passengers. In 1925 Blue Star Line ordered five large ships, known of as the A-class ${ }^{4}$. These vessels were completed two years later and carried 160-180 first class passengers particularly to and from Argentina, and also carried meat and other cargo. Modifications were made; the Avelona Star was converted to only carry cargo while the reverse was the case with the Arandora Star. The Arandora Star with its lavish furnishings and ballroom, swimming pool and tennis court, was the epitome of luxury cruising in the interwar years.

In 1933 the company began using refrigerated vessels to carry meat from Australia and New Zealand. An impetus to this was the preferential treatment accorded to the Dominions when the UK abandoned free trade. Farms on a gigantic scale were acquired in South America and Australia resulting in a most remarkable vertically integrated meat operation employing tens of thousands of people in the interwar years. All facets of the meat industry from the farm to the retail butchery were owned by the company and the shipping operation was just one link in the chain.

The Imperial Star class that followed in the 1930s and 1940s were motorships and while they carried passengers, they did not do so to the extent, or with the luxury, that the A-class did. The British Government pressed most of Blue Star Line's 38 vessels into service when the Second World War broke out in 1939. Twelve vessels remained in 1945. Blue Star Line's vessels were quite fast and frequently operated independently of the convoy system. The aforementioned A-class vessels could do 16 knots for example.

\section{Blue Star Line's War Service}

The Almeda Star was carrying passengers and cargo from Liverpool to the River Plate when she was torpedoed in 1941 by the German submarine U-96 ${ }^{\text {a }}$. Rescue parties were sent following a brief distress signal but they discovered no sign of her. The vessel was lost with all hands, including 194 passengers.

3 <http://www.bluestarline.org/william_vestey.htm>.

4 The Almeda, Andelucia, Arandora, Avelona and Avila. The name "Star" was added in 1929. 
The Andalucia Star was carrying meat, eggs and passengers from Argentina to England when she was torpedoed by U-101 at night off the coast of West Africa. During the evacuation the ship was repeatedly torpedoed. A four-year-old girl was discovered in the water some considerable distance from the lifeboats. A crewman swam to her and eventually they could be saved. The Stewardess that had turned on the girl's red electric safety light was never found. The lifeboats were later picked up by a Royal Navy corvette, miraculously only four lives had been lost.

The cruise liner Arandora Star was used as a troop and refugee transport in the first year of the war. In 1940 she was controversially tasked with transporting civilian Italian and German male internees, as well as German Pow's, to Newfoundland. The Arandora Star was torpedoed by U-47 off the coast of Ireland. A little over half of the people, many covered in fuel oil, were rescued on a Canadian destroyer sent for the purpose. Further searches discovered no further survivors. 805 people were lost and Blue Star Line never reused the name "Arandora".

The Avelona Star was the vessel that had been converted to only carry cargo. She was torpedoed by U-43 while in convoy carrying meat and oranges from Argentina. The survivors were picked by the French Beignon that was itself sunk later the same day. There were a few fatalities.

The Avila Star was carrying meat and passengers from Buenos Aires when she was torpedoed at night by U-201 in 1942. A further torpedo during evacuation caused additional casualties. The survivors of the sinking endured a tortuous journey in the lifeboats, with many fatalities due to wounds, dehydration and exposure before finally being rescued by Portuguese vessels. One of the lifeboats was lost at sea. 73 of the 199 people onboard perished.

Many of the other vessels of Blue Star Line suffered similar fates. A well known example is the Doric Star that was sunk by the infamous German "pocket-battleship" Admiral Graf Spee. While we are on the subject it ought to be mentioned that several Blue Star Line vessels were actively involved in military operations during the war, Norway and the Siege of Malta for instance. Blue Star Line lost 646 of its personnel during the Second World War and, as previously mentioned, most of its fleet.

Note: a See Taffrail, W. 1973. Blue Star Line at War, 1939-1945, London: Foulsham. An overview is available at $<\mathrm{http}: / /$ www.bluestarline.org $>$. 


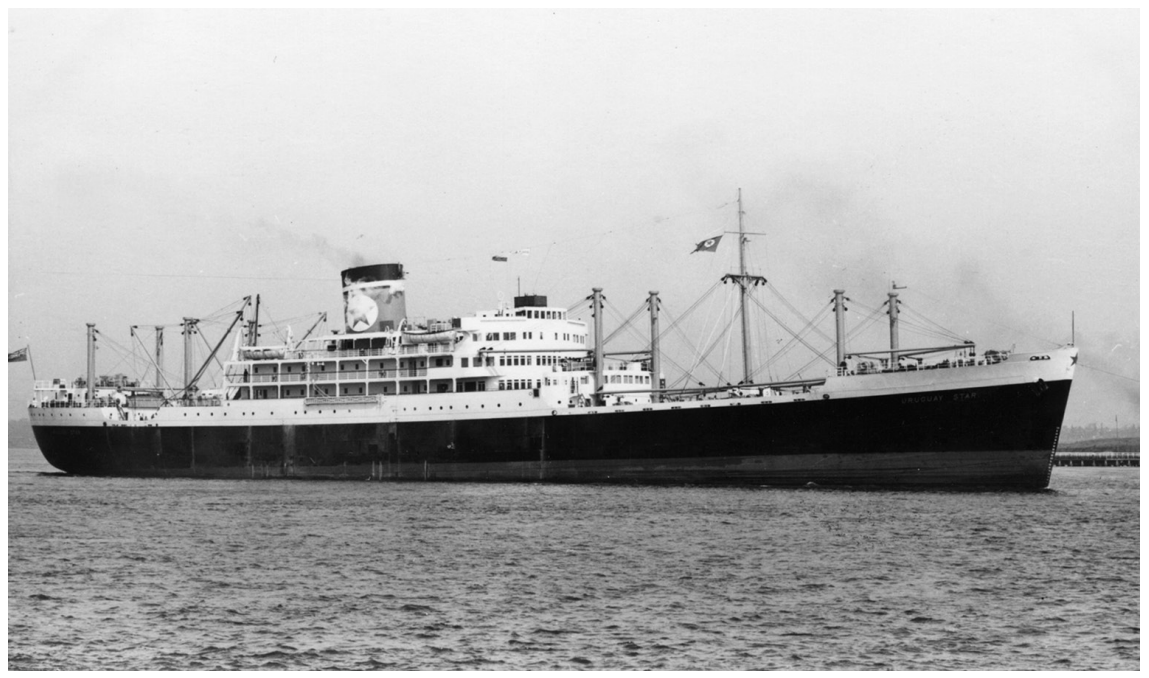

FIGURE 19 Prior to containerisation, many reefer cargoes, particularly meat, were carried in refrigerated cargo liners. Passengers were also carried, and vessels like the Uruguay Star had first class service PHOTO: BROWN, W.H./ SJÖHISTORISKA MUSEET

The British Ministry of War Transport built low-cost "Empire" ships during the war and some of these were purchased or chartered by Blue Star Line after the war ended to replace lost tonnage. Blue Star Line took over Lamport and Holt Line in 1944 and the Booth Steamship Company in 1946. Four replacements for the A-class were also ordered and completed in 1947 and 1948. These vessels were the Argentina Star, Brasil Star, Paraguay Star and the Uruguay Star. They resumed their first class service to South America but with fewer passengers and the luxury and opulence of the interwar era was a thing of the past.

\section{Entry into Specialized Reefers}

The link to Australia and Queensland's beef industry was identified by the names of vessels such as the Gladstone Star, Townsville Star, Queensland Star and Rockhampton Star in the late 1950s and early 1960s. These vessels and several other reefers that were built around the same time heralded the company's major entrance into specialised reefer shipping. The Wellington Star of 1952 was claimed to be the world's largest reefer at the time with a capacity of almost $600000 \mathrm{cbf}^{5}$. Services between New Zealand and Japan were

5 Collard, I. 2014. Blue Star Line: Fleet \& History, Gloucestershire: Amberley Books, p. 28. 
inaugurated and carried fruit as well as meat and fish. General cargo was also carried. A line that was later to become very important was started in 1962 carrying meat from Australia to the east coast of the USA and Canada. Many services were conducted jointly with other shipping operators.

Blue Star Line were pioneers in the field of containerised shipping. In 1966 they were one of the five British shipping companies that formed Associated Container Transport (АСт). The other members of the consortium were Ben Line, Cunard Steam Ship, Ellerman Lines and Harrison Line. In 1967 a corresponding company focused on Australia was formed ACT(A) by Blue Star Line, Ellerman Lines and Port Line. The funding of the new large container vessels required cooperation and the first of these vessels was the $A C T 1$ delivered in 1969. In the seventies there were various constellations of shipping companies including Blue Star Line that were concerned with containerised shipping ${ }^{6}$. The California Star and the Columbia Star were delivered in 1971 and besides carrying ordinary containers also carried 125 insulated containers for refrigerated cargo. Blue Star Line cooperated in the North Atlantic trade with the Danish East Asiatic Company as ScanStar which became Johnson ScanStar when the Swedish Johnson Line joined in 1972.

\section{Johnson Line}

The Swedish Johnson Line can trace its origins back to Axel Johnson's trading with coal, iron and steel in the late 19th centurya. Shipping enterprises followed and this included the Johnson Line, a liner company. The first Swedish vessels fitted with refrigeration were the Axel Johnson, Annie Johnson and Margaret Johnson operated by the Johnson Line after the mid-1920s. They were designed for the north Pacific trade and had refrigerated holds of $50000 \mathrm{cbf}$. Their cargoes included fresh fruit. Further liner vessels with refrigeration followed and the business with South and Central America grew. Several other Swedish companies operated similar vessels, such as Transatlantic, Swedish America Line, Swedish East Asia Company, Swedish Orient Line.Johnson expanded its reefer capacity with the Rio series (100 ooo cbf reefer) in the 1950s and also modified existing vessels to increase their refrigerated and freezer capacity. They collaborated with Atlanttrafik as well as German and Norwegian reefer operators and discussions were held with Salén so they were well acquainted with reefer operations. They were already chartering in reefers to service its fruit cargoes from Argentina, and this was expensive in the high

6 For further reading see for example Collard 2014. 
season, so in 1961 they ordered their first specialized reefers. The four Valley class vessels that followed were designed in-house, and had a capacity a little under $300000 \mathrm{cbf}$, had modern cranes and could do 19 knots. In 1968 , larger vessels, also referred to as Valley Class, were built and added to the fleet. These ships could do 22 knots and had a 487000 cbf capacity. Johnson's reefers were state of the art.

Johnson Line's focus was always on the liner business and similarly to other liner companies they experimented with refrigerated containers in the 1970s. Because of its involvement in the North-South trade particularly from Argentina, Johnson used refrigerated containers on their vessels. These vessels had a centralised refrigeration unit that was ducted to the insulated containers, the so-called porthole system. Johnson Line were in serious trouble around the time of the Salén bankruptcy in 1984, they pulled through, but the shipping operations later declined.

Note: a This section is mainly based on Rinman, T. 1990. The Johnson Line 1890-1990, Gothenburg: Rinman \& Lindén, pp. 88 \& 148-149. Also, Svensk Sjöfarts Tidning 1987/47 p. 14-19 \& 1987/49, p. 17-21.

The advent of containerisation, the growth of specialised reefer shipping as well as the emergence of affordable air travel all combined to end the era of the refrigerated cruise liner and these vessels were scrapped in the early seventies. Blue Star Line built six new reefers of around 500 ooo cbf, the new A-class, and their delivery announced the company's venture into the major fruit trades dominated by Saléns and Lauritzen-Peninsular Reefers. These larger, faster, and more technologically advanced vessels, starting with the Afric Star in 1975 were comparable to the Snow vessels built by Saléns just a few years earlier. Two of these A-class reefers were chartered by the British government for use as support vessels during the Falkland Islands conflict in 1982. Meat continued to be an important sector for Blue Star Line but the refrigerated sector expanded into the fruit market and with bananas in particular.

In 1983 the company placed a major order for four newbuildings from Harland \& Wolff of Dublin. The shipyard had built ships for Blue Star in the past and was also the birthplace of the Titanic. These vessels were the Scottish Star, Auckland Star, English Star and Canterbury Star of 465000 cbf and were delivered 1985-86. These modern vessels were more economical than those before. They were fuel efficient, had modern handling equipment, rationally designed to maximise pallet intake and could handle a large number of containers. The vessels also had the advantage of being able to function with a smaller crew: 21 
as compared to 36 with the A-class of the seventies? ${ }^{7}$. They were successfully put to work in the fruit trades.

On the container side Blue Star Line co-operated with amongst others Hamburg Süd on its South American services. The relationship with Hamburg Süd would become particularly significant on the reefer side a few years later. The meat trades in the eighties were increasingly containerised. Blue Star Line, as ACT, competed with Cool Carriers and Seatrade for some time with meat trades from Australia to the us East Coast. This was a battle between containerised shipping and specialised reefers. The containerised services enjoyed economies of scale but the small refrigerated vessels were quicker at clearing their palletised cargoes through customs in the USA. Eventually the business became containerised. These trades carried meat from ports such as Townsville, Brisbane and Darwin to Houston, Jacksonville and especially Philadelphia. The lean grass-fed Australian beef was ideal for hamburger patties that upon delivery at the Packer Avenue Terminal in Philadelphia went directly to the grinders and from there to well-known hamburger chains.

Blue Star Line's reefer division on other hand, was separate and quite small; in 1986 it was operating 17 reefers $^{8}$. It was primarily involved in the fruit trades but also carried other cargo. Blue Star Line and Hamburg Süd merged their reefer operations and formed Star Reefers in 1989. The new joint venture was operating 25 vessels in 1991. It was also around this time that it became public knowledge that the Vestey group had serious financial problems.

It was the conjuncture of several factors that caused the downfall of the Vestey empire in the 1990s. This complex series of events can be broken down to three components. Firstly, Union International which was particularly recognised by its ownership of the massive J.H. Dewhurst butchery chain. This was a major source of the group's problems. Union International had borrowed heavily to invest in expensive high street butcheries at the time when meat retailing was switching to the supermarkets. The hysteria surrounding Mad Cow Disease only served to exacerbate the problems.

Secondly, Blue Star Line ${ }^{9}$, besides being Britain's second largest shipowner, was a holding company for diverse shipping interests where the containerised trades to the United States were the largest. This part of the business had recently been expanded by the purchase of the North American interests of

7 Tolerton 2008, p. 155-156.

8 "Cool Carriers fortsätter världsledande kylsjöfart". Svensk Sjöfarts Tidning 46/1986, pp. 35-40.

9 Owned in turn by Frederick Leyland which was the name of a shipping company acquired in 1935 . 
ACT(A) when Cunard Ellerman sold its stake to P\&O. Blue Star Line controlled Pacific Express Container Line, Booth Line and many other liner services as well as shipmanagement and its stake in Star Reefers, but profits were elusive. During the nineties Blue Star Line tried to improve its profitability by flagging out vessels and cutting costs which impacted on its British crews. The shipping interests of the Vesteys were struggling and during these years usually recorded a net loss.

The third major part of the Vestey group were its property holdings. The agricultural holdings in South America and Australia were vast and a couple of hundred thousand beef cattle ranged upon them. These solid property investments were, however, coupled with more recent speculative investments in commercial real estate, in London, and their timing was unfortunate.

So the three major parts of the Vestey empire had their own problems, to varying degrees. An additional problem that surfaced at the same time was that it became increasingly difficult for the Vestey Group to minimise its tax payments to Inland Revenue. Debts were rising and the outlook was unfavourable.

Edmund Hoyle Vestey, the Chairman of Blue Star Line, had meetings with the banks. Huge properties in Australia were sold in 1992 as a part of the plan negotiated with the banks to refinance the debts of Union International. Sir John Collins was brought onboard by the banks as Chief Executive of the Vestey Group in 1993. Until 2001, he led the process of dismantling the group in the interests of creditors. Union International could not be saved and was put into receivership in 1995. Blue Star Line, with the exception of Star Reefers, was sold to P\&O Nedlloyd in $1998^{10}$. However, Blue Star Line acquired Hamburg Süd's part of Star Reefers. The Vestey's shipping operation was then confined to Albion Reefers as the ship owning company with six reefers ${ }^{11}$ and Star Reefers as the operating company that also included vessels on charter. Star Reefers' present-day CEO Kenneth Ross remembers the period as "biblically bad basically". Efforts were made to find another reefer operator to partner with. United Reefers, linked to the Dutch ship owner Vroon was an option that was explored but ultimately the choice settled on was NYK Reefers. However, as these matters were being discussed, the Vestey Group found a buyer for the reefer business. Christian Siem after rebuilding the ailing Swan Reefers was now set to purchase Star Reefers. This signalled the end of the Vestey's involvement in shipping. They retain substantial property holdings and some food

$10 \quad$ P\&O Nedlloyd was acquired by AP Møller-Maersk in 2006.

11 The above mentioned Scottish Star, Auckland Star, English Star and Canterbury Star as well as the slightly older Tudor Star and Trojan Star. 
interests. In the next section we will go back a few years and briefly look at Swan Reefers and then proceed to look at the recent history of Star Reefers as a part of the Siem group.

\section{Swan Reefer}

Swan Shipping was founded in 1984 by the captains Christer Jansson, Lars Ericsson and the chief engineer Bill Jansson. They purchased their first vessel, a ro-ro, by using their own homes as security. The company had been founded on the Swedish west coast but moved to Norway in the late eighties to attract capital. Bulk carriers were purchased from Klaveness and were operated in the Klaveness Bulkhandling Pool. Swan Shipping also owned reefers and ro-ro vessels that freighted forest products.

The company expanded its fleet but profits were elusive. The focus shifted to reefers. Swan Reefer was formed in 1997 with Actinor and Swan Shipping as the main owners. Actinor, besides its other interests, owned four reefers that were bareboat chartered to Del Monte and Lauritzen. Swan Shipping had five reefers at the time that Swan Reefer was formed. A tenth reefer was purchased from Chilean CAV and after a successful share emission another eight from Irgens Larsen. The rapid expansion coincided with a declining market and mounting losses with the result that the company's share price dropped sharply. Ugland began buying into the company and efforts were made to reduce costs. In 1999 Swan Shipping sold its share of the company leaving Ugland and Actinor as the largest owners.

Swan Reefer, as with other Norwegian-based ventures in the reefer market, was focused on ship owning as an investment and not as a commercial shipping operation. Most of Swan's vessels were operated in the Cool Carriers and Lauritzen pools. The company struggled and its situation became precarious when banks and investors began to lose faith. A new owner was sought, and in December 2000 it was announced that Christian Siem, of Siem Industries, was buying in. Siem was well known in shipping circles as a contrarian investor with the ability to turn things around. In order to ensure good returns, Swan needed a commercial operation. This meant that more ships were required as well as the know-how to operate them. Therefore, it was speculated that an additional acquisition was in the pipeline. 


\section{3}

\section{Star Reefers}

The reinvigorated Swan Reefer, led by Christian Siem, acquired Albion Reefers in 2001 for USD 35 million, completing the Vesteys' exit from shipping. For this relatively low price, Siem gained six reefers, a first class brand with deep customer relationships, and the management and marketing expertise required to operate his growing fleet. Swan Reefer was renamed Star Reefers the operations were placed in the Star Reefers London office. Apprehensions at Star that Siem was a speculative investor proved to be unfounded; Siem was in for the long haul.

Discussions of Star Reefers forming a joint-venture with NYK Reefers were already underway when Siem entered the scene. Consolidation was considered to be a sound strategy in the face of a difficult market. And NYK Reefers, from Star's perspective, was seen as a suitable business partner. Both companies had similar ships and customers. The business idea was also similar; both companies chartered out tonnage to the major fruit companies. And both companies were generally conservative long-term players in the industry; on paper it seemed like a good match.

A joint pool agreement was reached in late 2001 between Siem's Star Reefers and NYK. This was the start of NYK Star Reefers, a joint-venture that although short-lived, was seen as a major industry consolidation at the time. NYK Star Reefers operated seventy-four ships and was the second largest player in the industry; only LauritzenCool, also a consolidation, was larger.

Aage Thoen headed up the new operation and Kevin Harding, long-time manager at Star, continued in a senior capacity. On the NYK side, Fumiya Aoki was in charge. The office was a combined operation and people were employed by either NYK or Star and in a similar fashion the vessels belonged to one company or the other. Managing the joint-venture turned out to be difficult, each side prioritised its own interests and personalities were also a factor. There was a perception from NYK that their interests were coming off second best so in an effort to remedy this they recruited Lars Rutberg from LauritzenCool to oversee the operation. This move was perceived by managers at Star Reefers as confrontational. Star Reefers also had former Swan Reefer vessels still in the LauritzenCool pool and wanted to bring them over to the NYK Star Reefer Pool. Both NYK and Star had to agree on the terms placed on vessels entering the pool, and in this case, NYK effectively stopped the move. It later surfaced that NYK were already in talks with LauritzenCool. Later, when these bore fruit, Star Reefers was offered a role in NYK's new operation on terms that Star, however, would not accept. The joint-venture was terminated in late 2003 and the two companies went their separate ways. In the same year, Laskaridis made an 
unsolicited bid for Star Reefers, offering 7om USD and taking over 121m USD in debt. However, the offer was declined, possibly because of a promising market outlook.

Star Reefers operated 36 reefers in 2004 and around half of these were owned and the remainder were chartered in. The market boomed, rates on the spot market were, for larger vessels such as those operated by Star, up $27 \%$ from the year before, and were the best since 1997. Fixed twelve month charters were similarly climbing and the general demand for shipping assisted in fixing backhaul cargo (e.g. second-hand cars).

The Japanese ship owning company Nissen Kaiun was a key partner for Star Reefers. The general modus operandi that emerged over the years was that Nissen built new vessels at the Shikoku Yard and chartered them to Star Reefers who in turn chartered them out to the major fruit companies. After a number years Star purchased the vessels, sold or scrapped its old ones, and Nissen built new ones. In 2004 Star Reefers entered into 10 year time-charters for the first of what was eventually to become the 12 newbuildings of the Star class.

Deliveries of these modern and large (615 0oo cbf) vessels commenced in 2006 and were profitably chartered out in batches of four to major fruit companies. Star First was the first of the twelve and its name is something of a play on words: it's the first vessel of the class, and all twelve begin rather than end with the word 'Star', as had been the company's practice since the 1920s. The Star class vessels are the largest investment in reefer newbuildings so far in the $21^{\text {st }}$ century. They ensure that Star Reefers can supply quality tonnage to the market and to the banana companies in particular. The vessels have a large reefercontainer capacity, modern handling equipment and are more fuel efficient than older vessels. Star Reefers successively purchased older vessels in its operation including the Caesar reefer vessels from Oetker, Polar class from M PC, and the $\mathrm{C}$ class from Nissen. Star Reefers also developed an in-house shipmanagement subsidiary in Gdynia, Poland starting in 2006. The technical management of all of their owned vessels was eventually transferred to this operation.

In the booming market until 2008, Star Reefers was able to fix most of its fleet each year on timecharters at profitable rates and the newbuildings had long-term arrangements in place. The small portion of the fleet that traded on the volatile spot market could take advantage of the usually high rates that prevailed at the time. Russia had emerged as a major destination for specialised reefer cargoes. As a consequence, Star had several of its vessels ice-strengthened, which was a prerequisite to reach St Petersburg in the winter months. Five vessels were placed on long-term time charter with the Russian fruit importer Sunway and in 2008 also to the Joint Fruit Company. 


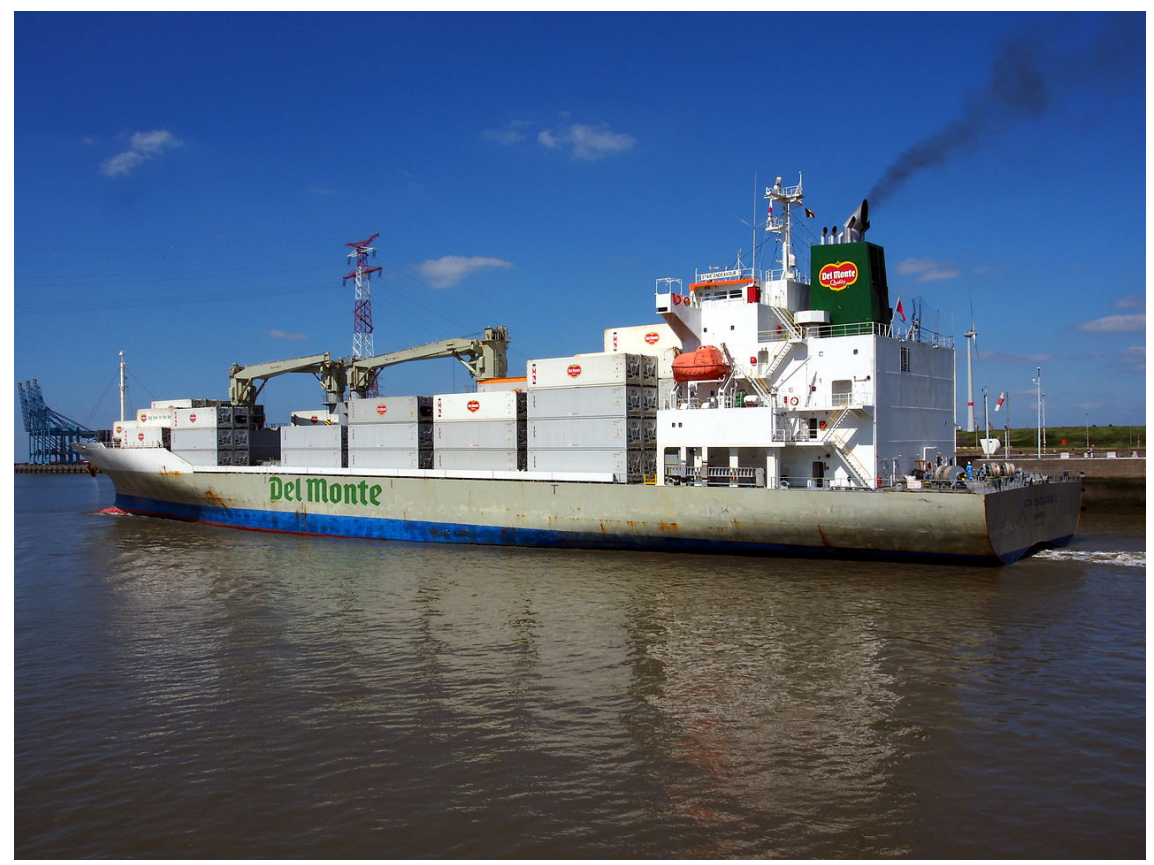

FIGURE 20 The Star First class is the largest series of reefers built in the $21^{\text {st }}$ century. Pictured is the Star Endeavour, here on charter to Del Monte, leaving Antwerp in 2012 PHOTO: ALFVANBEEM

However, 2008 was also the year that the market started to slide as the global recession impacted. Scrapping prices were still high and many owners of older vessels took advantage of this. Star didn't take this opportunity and their vessels continued to trade profitably for a time. Star managed to record a profit in 2009 despite the market downturn due to its previously negotiated time charters. The recession also coincided with poor fruit harvests in Central America, poor squid catches in the South Atlantic, reduced poultry trade between the USA and Russia as well as high bunker prices. Reefer cargo rates were also driven down as a result of container line overcapacity. The combination of reduced supply, demand, financing and increased cost and competition from container lines caused the spot market to plummet to levels well below that necessary to cover operating expenses. Russian fruit importers encountered difficulties and returned their chartered vessels to Star which in turn exposed the vessels to the spot market with losses as a result. Star was eventually able to re-establish its connection to this trade with a contract to Banex that provided for a weekly service between Ecuador and St Petersburg. 
Star's fleet reached a total of 46 reefers but the state of the market had forced several of them into lay-up. Shippers were avoiding fixing their tonnage requirements on timecharters and instead took advantage of the low prices that prevailed in the spot market. Star began scrapping older vessels when scrapping prices improved in 2011. Some vessels were also sold. Star was able to return to a modest level of profitability when the market improved in 2013. The "C" class vessels Caribbean Star, Costa Rican Star, Cote d'Ivoirian Star, and Colombian Star were lengthened and had new cranes fitted in 2013 and 2014. The four rejuvenated vessels were chartered to Africa Express Line.

Siem Industries, the holding company, diversified its shipping interests into the transport of automobiles with Siem Car Carriers. Two Star First vessels were purchased from Nissen in 2015 and this was followed by an agreement to timecharter two newbuildings from the same owner and the same Shikoku Shipyard. These new ships, the Star Spirit and the Star Courage, have a capacity of $650000 \mathrm{cbf}$ under deck and can carry approximately 300 refrigerated containers ${ }^{12}$. As of 2016 Star Reefers operates 28 vessels mainly in the banana trade, and their average age is about 15 years.

\section{Summary}

Blue Star Line was similarly to the Japanese shipping companies a liner operation that expanded into the the specialized reefer trades as a complement to their liner business. Also, similar to NYK, Blue Star Line could not integrate the specialized reefer operations into the liner business, due to operational differences. The specialized reefer division came to live a fairly independent life, which consolidated with Hamburg Süd into Star Reefers in the late 1980s to increase their market presence. Due to the problems in the Vestey group Star Reefers declined during the 199os and similarly to Lauritzen they knew that if they couldn't consolidate with another actor they were doomed to a slow decline. At this point in time NYK Reefer had established their main office in London and it was agreed to start a joint operation. The two parties fit perfectly, both being liner companies. However, before the joint venture materialized, Star Reefers was purchased by the Swan Reefer group led by the shipping investor Christian Siem in 2001. At first this was perceived by the market as a predatory investment basically for the hard assets, and this was most probably due to the subjective perception of Christian Siem as an outsider who also had

12 Press Release of Siem Shipping Inc. 10 January 2016. Report for the first nine months and third quarter 2016. 
done good M\&As in the past. NYK Reefer perceived the collaboration to be biased and looked for an alternative partner. Star Reefers has after 2003 expanded their fleet with newbuildings in collaboration with Nissen, which is the largest newbuilding programme in the first decade of the 2000s. Around 2010, Star's fleet peaked at 46 vessels but declined to 28 vessels as of 2016. Star Reefers discursively position itself as a modern, high-class partner to the fruit companies, and the perception of Christian Siem as a short-term opportunist is gone. 